\title{
DEPRESI BERHUBUNGAN DENGAN KUALITAS HIDUP LANSIA DI PANTI SOSIAL TRESNA WERDHA DI JAKARTA
}

\author{
A.A. Ayu Rani Puspadewi*, Etty Rekawati \\ Fakultas Ilmu Keperawatan Universitas Indonesia, Depok 16424, Indonesia \\ *E-mail: ranipuspadewi@gmail.com
}

\begin{abstract}
Abstrak
Setiap orang dapat mengalami depresi, salah satunya adalah lansia, dimana lansia memiliki konsekuensi fungsional yang lebih serius dibandingkan dengan tingkat pertumbuhan lainnya, mulai dari kualitas hidup yang negatif hingga bunuh diri. Tujuan penelitian adalah untuk mengetahui hubungan antara depresi dengan kualitas hidup lansia. Sampel penelitian adalah lansia $\geq 60$ tahun yang tinggal di Panti Sosial Tresna Werdha Budi Mulia 1 Jakarta, mampu berkomunikasi dengan bahasa Indonesia, serta bersedia menjadi responden. Jenis penelitian ini menggunakan desain penelitian cross sectional dengan metode simple random sampling yang melibatkan 101 lansia. Hasil penelitian menunjukkan adanya hubungan antara tingkat depresi dengan kualitas hidup lansia $(\mathrm{p}=0,017 ; \alpha=0,10)$. Penelitian ini diharapkan dapat berguna untuk pengembangan ilmu keperawatan di masa yang akan datang terkait peningkatan kualitas hidup lansia dengan cara menangani depresi lansia.
\end{abstract}

Kata Kunci: Depresi, Kualitas Hidup, Lansia, Panti Sosial Tresna Werdha

\begin{abstract}
Depression in Relation with the Quality of Life Elderly in Nursing Home Jakarta. Depression could experienced by anyone, such as elderly whose fuctional consequences is experienced more serious such as low quality of life and the worst one is suicidal. The purpose of this research was to find the relationship between depression and quality of life in elderly. The research sample was elderly aged 60 and over who live at Institutionof Elderly Budi Mulia 01 Jakarta, speak Bahasa, and willing to be a respondent. This research used cross sectional study design with simple random sampling method which involved 101 elderly. The result of this study showed that there was significant relation between level of depression and quality of life in elderly $(p=0.017 ; \alpha=0.10)$. This research is expected to be useful for nursing science development in the future, spesificly on preventive of quality of life decreased by handling depression in elderly.
\end{abstract}

Keywords: Depression, quality of life, elderly, nursing homes

\section{Pendahuluan}

Lanjut usia (lansia) merupakan tahap akhir pada setiap siklus kehidupan manusia. Menurut WHO (2010) dalam Banon (2011), batasan lansia adalah seseorang yang telah berusia 60 tahun atau lebih. Dalam Undang-undang No. 13 tahun 1998 tentang kesejahteraan lansia, yang termasuk lansia adalah seseorang yang telah berusia 60 tahun atau lebih. Berdasar hasil Susenas tahun 2013, jumlah lansia di Indonesia mencapai 20,04 juta orang atau sekitar 8,05 persen dari seluruh penduduk Indonesia (BPS, 2013).
Seiring bertambahnya usia, banyak perubahan yang terjadi seperti, lansia yang kehilangan pekerjaan, beresiko terkena penyakit, kesepian, dan lain sebagainya. Perubahan tersebut dapat membuat lansia mengalami perubahan mental, salah satunya adalah depresi. Menurut World Health Organization (WHO, 2012), depresi merupakan gangguan mental yang ditandai dengan perasaan bersalah atau harga diri rendah, gangguan tidur dan makan, kehilangan kesenangan, dan penurunan konsentrasi. Dampak terbesar yang sering terjadi akibat depresi adalah kualitas hidup yang menurun dan meng- 
hambat pemenuhan tugas-tugas perkembangan lansia (Stanley dan Beare, 2006).

Menurut WHO QOL (Yuliati dan Ririanty, 2014), kualitas hidup adalah persepsi individu terhadap kehidupannya di masyarakat dalam konteks budaya dan sistem nilai yang ada yang terkait dengan tujuan, harapan, standar, dan perhatian. Kualitas hidup merupakan suatu konsep yang sangat luas yang dipengaruhi kondisi fisik, psikologis, tingkat kemandirian dan hubungan individu dengan lingkungan.

Sebagian besar penduduk lansia di Indonesia tinggal bersama keluarganya di rumah. Namun, ada juga lansia yang tinggal di panti werdha. Perbedaan lingkungan tempat tinggal ini memunculkan perbedaan lingkungan fisik, sosial, ekonomi, psikologis, serta spiritual (Wulandari, 2011). Perbedaan ini dapat menyebabkan lansia mengalami depresi. Menurut Darmono (2008) dalam Syarniah (2010), prevalensi depresi pada lansia yang menjalani perawatan di Rumah Sakit dan panti $30-45 \%$. Frazer, Christensen \& Griffith (2005) dalam Syarniah (2010), menyebutkan prevalensi depresi di unit komunitas lebih bervariasi yaitu berkisar antara $1-35 \%$.

Peningkatan jumlah lansia, seiring dengan peningkatan individu yang memerlukan pengobatan dan perawatan. Hal ini berarti bahwa sumber pelayanan kesehatan harus lebih terjangkau (Watson, 2003). Perhatian pemerintah, khususnya Dinas Sosial terhadap lansia yang terlantar adalah dengan dibangunnya panti sosial khusus untuk lansia (Panti Werdha). Panti werdha memiliki tugas pokok dan fungsi yaitu menyelenggarakan pelayanan kesejahteraan lansia terlantar meliputi perawatan, pembinaan fisik, mental dan sosial.

Sinichi Deruma dan Samusu Sato (2003) dari Kanazawa University menyatakan terdapat hubungan antara depresi, gaya hidup, dan kualitas hidup lansia. Dalam penelitiannya ini Sinichi dan Samusu membandingkan depresi, gaya hidup, dan kualitas hidup dengan kelompok jenis kelamin dan usia pada lansia yang berada di komunitas. Dari penelitian ditemukan bahwa depresi lebih rentan dialami oleh lansia wanita yang termasuk usia sangat tua serta terdapat hubungan antara depresi dengan kualitas hidup.

Ibrahim et al. (2013) juga melakukan penelitian hubungan antara dukungan sosial dan depresi, dan kualitas hidup pada lansia yang berada di komunitas pedesaan di Malaysia. Dari penelitian didapatkan hasil bahwa depresi yang dialami lansia di pedesaan rendah yakni sekitar $23,5 \%$ dan dengan kualitas hidup yang tinggi.

Beberapa penelitian diatas menyebutkan angka depresi yang terjadi di rumah sakit ataupun di panti lebih besar dibanding angka depresi di komunitas. Oleh karena itu, peneliti tertarik untuk melakukan penelitian mengenai hubungan tingkat depresi dengan kualitas hidup lansia di Panti Sosial Tresna Werdha Budi Mulia 1 Jakarta.

\section{Metode}

Penelitian ini merupakan penelitian jenis kuantitatif bersifat deskriptif korelatif dengan menggunakan pendekatan cross sectional, Proses pengukuran variabel independen dan dependen hanya dilakukan satu kali, setelah itu tidak dilakukan tindak lanjut (Budiarto, 2004).

Sampel penelitian adalah 101 lansia di Panti Sosial Tresna Werdha Budi Mulia 1 Jakarta yang terletak di dua tempat yakni di Cipayung dan Ciracas. Teknik pengambilan sampel yang digunakan peneliti yaitu simple random sampling. Simple random sampling merupakan teknik pengambilan sampel secara acak sederhana (Dharma, 2011). Kriteria inklusi sampel penelitian yaitu lansia yang tinggal di Panti berusia $\geq 60$ tahun, mampu berkomunikasi dengan bahasa Indonesia, serta bersedia menjadi responden.

Pengambilan data dilakukan dengan menggunakan kuesioner sebagai instrumen penelitian yang dibacakan kepada lansia. Kuesioner yang digunakan terdiri dari 3 bagian. Kuesioner 
1 berisi tentang data demografi, bagian 2 berisi pertanyaan tentang depresi dan bagian ke 3 mengenai kualitas hidup lansia. Instrumen depresi menggunakan Geriatric Depression Scale $(G D S)$ dengan 30 pertanyaan dan Instrumen kualitas hidup menggunakan WHOQOL-BREF dengan 26 pertanyaan.

Data diolah dan diproses menggunakan sistem program komputer. Data dianalisis secara univariat dan bivariat dengan uji proporsi pada setiap variabel penelitian, meliputi karakteristik responden, tingkat depresi dan kualitas hidup lansia. Uji Chi square dengan kemaknaan $\mathrm{p}<$ 0,10 digunakan untuk mengetahui hubungan antara tingkat depresi dengan kualitas hidup lansia.

\section{Hasil}

Karakteristik Responden. Usia lansia yang paling mendominasi pada penelitian ini yaitu di tahap lansia sebesar $-69,3 \%$, lebih dari setengah responden berjenis kelamin perempuan (64,
4\%), berasal dari suku Jawa 46,5\%, lebih dari setengah $(55,4 \%)$ tidak tamat SD, mayoritas beragama Islam $(-78,2 \%)$, saat penelitian dilakukan 38,6\% responden memiliki keluhan arthritis.

Berdasarkan analisis tingkat depresi bahwa lansia yang memiliki depresi didominasi oleh lansia dengan tingkat usia pada tingkat usia lansia, berjenis kelamin perempuan, suku Betawi,berasal dari tingkat pendidikan dasar, lansia beragama Budha, dan dengan keluhan penyakit kulit. Berdasarkan analisis kualitas hidup ditemukan bahwa lansia yang memiliki kualitas hidup yang baik didominasi oleh lansia dengan tingkat usia lansia tua, berjenis kelamin laki-laki, tingkat pendidikan tinggi, beragama Budha dan lain-lain, serta lansia yang tidak memiliki keluhan kesehatan.

Tingkat Depresi. Berdasarkan Tabel 1 dapat dilihat bahwa jumlah lansia yang mengalami depresi sebesar $57,4 \%$ yang diukur menggunakan instrumen penelitian GDS.

Tabel 1. Tingkat Depresi Lansia

\begin{tabular}{lccc}
\hline & Tingkat Depresi & Jumlah (n) & Persentase (\%) \\
\hline Normal & 43 & $42,6 \%$ \\
Depresi & 58 & $57,4 \%$ \\
Total & 101 & $100 \%$ \\
\hline
\end{tabular}

Tabel 2. Kualitas Hidup Lansia

\begin{tabular}{lccc}
\hline & Kualitas hidup & Jumlah (n) & Persentase (\%) \\
\hline Tidak baik & 47 & $46,5 \%$ \\
Baik & 54 & $53,5 \%$ \\
Total & 101 & $100 \%$ \\
\hline
\end{tabular}

Tabel 3. Hubungan Tingkat Depresi Dengan Kualitas Hidup Lansia

\begin{tabular}{|c|c|c|c|c|c|c|c|}
\hline \multirow{3}{*}{ Tingkat Depresi } & \multicolumn{4}{|c|}{ Kualitas hidup } & \multirow{2}{*}{\multicolumn{2}{|c|}{ Total }} & \multirow{3}{*}{$\mathbf{p}$} \\
\hline & \multicolumn{2}{|c|}{ Baik } & \multicolumn{2}{|c|}{ Tidak Baik } & & & \\
\hline & n & $\%$ & $\mathbf{n}$ & $\%$ & n & $\%$ & \\
\hline Normal & 29 & 67,4 & 14 & 32,6 & 43 & 100 & \multirow{3}{*}{0,017} \\
\hline Depresi & 25 & 43,1 & 33 & 56,9 & 58 & 100 & \\
\hline Total & 54 & 53,5 & 47 & 46,5 & 101 & 100 & \\
\hline
\end{tabular}


Kualitas Hidup. Berdasarkan Tabel 2, dapat dilihat bahwa jumlah lansia yang memiliki kualitas hidup yang baik sebanyak $53,5 \%$.

\section{Hubungan Tingkat Depresi dengan Kualitas} Hidup. Berdasarkan Tabel 3, diperoleh hasil bahwa ada perbedaan yang signifikan pada nilai kualitas hidup pada lansia yang tidak depresi dengan lansia yang depresi $(\mathrm{p}=0,017)$.

\section{Pembahasan}

Hasil uji statistik bivariat diperoleh nilai $\mathrm{p}=$ 0,017 maka dapat disimpulkan ada hubungan antara tingkat depresi dengan kualitas hidup. Hasil ini didukung dengan hasil penelitian yang dilakukan oleh Deruma dan Sato (2003) dari Kanazawa University, yang menyatakan bahwa terdapat hubungan yang signifikan antara depresi, gaya hidup, dan kualitas hidup lansia. Dalam penelitian yang dilakukan oleh Deruma dan Sato ini didapatkan juga hasil depresi lebih rentan dialami oleh lansia yang tergolong lansia sangat tua dan berjenis kelamin perempuan. Hasil penelitian ini didukung oleh data dari Myers et al. (1984) (dalam Ellison dan Verma, 2003), estimasi keseluruhan depresi mayor yang terjadi pada lansia diperkirakan $1 \%$ lebih rendah dari orang yang lebih muda. Sampel perempuan memiliki angka depresi yang tinggi $(1,4 \%)$ daripada laki-laki $(0,4 \%)$. Analisis sekunder dari National Health examination Follow-up Study (Zonderman dan Costa, 1991) (dalam Ellison dan Verma, 2003), tidak mengamati cukup besar perbedaan prevalensi dari gejala di seluruh kehidupan dengan kemungkinan satu pengecualian. Lansia sangat tua dilaporkan menduduki angka tertinggi untuk gejala depresi dibanding yang lain.

Dalam penelitian ini juga dilakukan analisis tingkat depresi berdasarkan karakteristik responden. Adapun hasilnya adalah sebagai berikut, dari hasil analisis tingkat depresi berdasarkan usia didapatkan lansia yang banyak mengalami depresi adalah lansia yang berasal dari kategori usia lansia (60-74 tahun) yakni 61,4\%. Menurut Sharma dan Copeland (1989, dalam Manthorpe, dan Iliffe, 2005), sedikitnya satu dari 10 orang berusia 65 tahun atau lebih memiliki gejala depresi yang sangat signifikan seperti kesedihan, kehilangan tenaga, dan susah tidur. Hal ini sejalan dengan data BPS 2013, presentase penduduk lansia usia 60 tahun ke atas berkisar sebesar 8,05\%, usia 70 tahun ke atas sebesar $3,15 \%$, serta 80 tahun ke atas sebesar $0,85 \%$. Jadi, dapat dikatakan perbedaan hasil penelitian ini dan penelitian yang dilakukan oleh Deruma dan Sato adalah dikarenakan usia harapan hidup di Indonesia yang berdeda dengan usia harapan hidup di negara lain. Menurut jenis kelamin, lansia yang rentan mengalami depresi adalah lansia perempuan. Hasil ini sejalan dengan penelitian yang dilakukan oleh Deruma dan Sato. Dalam Kring, Johnson, Davison, dan Neale (2013), juga disebutkan jika perempuan memiliki risiko dua kali lipat lebih banyak untuk mengalami depresi mayor dibandingkan laki-laki.

Hasil penelitian juga didukung dengan hasil penelitian yang dilakukan oleh Ibrahim et al. (2013), yang meneliti hubungan antara dukungan sosial dan depresi, dan kualitas hidup pada lansia yang berada di komunitas pedesaan di Malaysia. Dari penelitian ini didapatkan bahwa kualitas hidup yang baik dengan depresi yang rendah memiliki hubungan yang erat untuk kesejahteraan psikologis. Komponen kualitas hidup dapat dibedakan menjadi tiga yaitu, kesejahteraan dan tingkat kehidupan, fungsi peran, dan faktor lingkungan. Faktor-faktor dari lingkungn fisik itu menentukan derajat dari batasan yang akan dicapai pada tingkat kualitas hidup individu, salah satu contoh faktor lingkungan adalah dukungan sosial (Katschnig, Freeman dan Sartorius, 2006). Selain itu, menurut Chew-Graham, Burns, dan Baldwin (2008), faktor-faktor pencegah dari depresi salah satunya adalah dukungan sosial. Sehingga sesuai dengan penelitian yang dilakukan oleh Ibrahim et al. (2013), nilai depresi lansia yang tinggal di lingkungan pedesaan lebih kecil dibandingkan dengan penelitian yang peneliti lakukan di panti sosial. Hal ini dikarenakan dukungan sosial yang diperoleh oleh lansia di 
pedesaan lebih baik dibandingkan dukungan sosial yang lansia peroleh di panti sosial. Namun, kondisi kualitas hidup lansia yang tinggal di pedesaan maupun lansia di panti sosial sama-sama memiliki kualitas hidup yang baik.

Berdasarkan hasil penelitian ini, dibutuhkan tenaga keperawatan yang secara komprehensif mampu melakukan asuhan keperawatan untuk menanggulangi masalah depresi dan kualitas hidup yang terjadi. Beberapa cara yang dapat dilakukan oleh perawat dalam menanggulangi masalah depresi dengan kualitas hidup antara lain, menciptakan dukungan sosial yang baik, perilaku koping, berolahraga, dan hubungan keagamaan. Selain itu, penelitian ini diharapkan dapat menambah keilmuan keperawatan komunitas mengenai hubungan tingkat depresi dengan kualitas hidup lansia.

\section{Kesimpulan}

Sebagian besar lansia dengan rentang usia 6074 tahun dan berjenis kelamin perempuan, hampir setengah dari lansia berasal dari suku Jawa, mayoritas lansia tidak tamat sekolah dasar dan beragama islam, rata-rata lansia mengeluhkan penyakit arthritis saat penelitian dilakukan. Lebih dari setengah lansia di panti mengalami depresi. Lebih dari setengah lansia di panti memiliki kualitas hidup yang baik. Berdasarkan analisis tingkat depresi berdasarkan karakteristik responden ditemukan bahwa lansia yang memiliki depresi didominasi oleh lansia dengan tingkat usia pada tingkat usia lansia, berjenis kelamin perempuan, suku Betawi,berasal dari tingkat pendidikan dasar, lansia beragama Budha, dan dengan keluhan penyakit kulit. Berdasarkan analisis kualitas hidup berdasar karakteristik responden bahwa lansia yang memiliki kualitas hidup yang baik didominasi oleh lansia dengan tingkat usia lansia tua, berjenis kelamin laki-laki, suku, tingkat pendidikan tinggi, beragama Budha dan lain-lain, serta lansia yang tidak memiliki keluhan. Ada hubungan antara tingkat depresi dengan kualitas hidup lansia.
Hasil penelitian diharapkan dapat menjadi dasar bagi perawat untuk melakukan asuhan keperawatan. Berdasarkan hasil penelitian ini, dibutuhkan tenaga keperawatan yang mampu memberi asuhan keperawatan secara komprehensif, dari proses pengkajian depresi hingga evaluasi, sehingga angka depresi yang terjadi pada lansia yang berada di panti dapat berkurang dan menyebabkan kualitas hidup lansia menjadi semakin baik. Kolaborasi dengan tenaga medis lain juga diperlukan demi meningkatkan kesehatan lansia (INR, ER, PN).

\section{Referensi}

Badan Pusat Statistik. (2013). Statistik penduduk lanjut usia. Diperoleh dari http://www. bps.go.id/webbeta/website/flipping_publikas i/stat_lansia_2013/indexFlip.php

Banon, E. (2011). Pengaruh terapi reminiscene dan psikoedukasi keluarga terhadap kondisi depresi dan kualitas hidup lansia di Katulampa Bogor tahun 2011 (Tesis, Program Studi Magister). Depok: Fakultas Ilmu Keperawatan Universitas Indonesia.

Budiarto, E. (2004). Metodologi penelitian kedokteran: Sebuah pengantar. Jakarta: EGC.

Dharma, K.K. (2011). Metodologi penelitian keperawatan: panduan melaksanakan dan menerapkan hasil penelitian. Jakarta: CV. Trans Info Media

Demura, S., \& Sato, S. (2003). Relationship between depression, lifestyle, and quality of life in the community dwelling elderly: A comparison between gender and age group. $J$ Physiol Athropol, 22 (3), 159-166.

Ellison, J.M., \& Verma, S. (2003). Depression in later life: A multidisciplinary psychiatric approach. New York: Marcel Dekker, Inc.

Chew-Graham, C.A., Burns, A.S., \& Baldwin, R. (2008). Integrated management of depression in the elderly. UK: Cambrige University Press. 
Ibrahim, N., Din, N.C., Ahmad, M., Ghazali, S.F. Said, Z., Shahar, S., ... \& Razali, R. (2013). Relationships between social Support and depression, and quality of life of the elderly in a rural community in Malaysia. AsiaPacific Psyciatry, 5 (S1), 59-66.

Katschnig, H., Freeman, H., \& Sartorius, N. (2006). Quality of life in mental disorders (2nd Ed.). England: John Wiley, Ltd.

Kring, V.A., Johnson, S., Davison, G.C., \& Neale, J.M. (2013). Abnormal psychology. International student version (12th Ed.). Singapore: John Wiley \& Son.

Manthorpe, J., \& Iliffe, S. (2006). Depression in later life. London and Philadelphia: Jessica Kingsley Publishers

Miller, C.A. (2012). Nursing for wellness in older adults (6th Ed.). Philadelphia: Lippincott Williams \& Wilkins.

Stanley, M., \& Beare, P.G. (2006). Buku ajar keperawatan gerontik. Diterjemahkan oleh Nety Juniarti dan Sari Kurnianingsih. Jakarta: EGC.
Syarniah. (2010). Pengaruh terapi kelompok reminiscence terhadap depresi pada lansia di panti sosial tresna werdha budi sejahtera provinsi kalimantan selatan. Depok: Fakultas Ilmu Keperawatan Universitas Indonesia.

Watson, R. (2003). Perawatan pada lansia. Diterjemahkan oleh: Egi Komara Yudha. Jakarta: EGC.

World Health Organization. (2012). Depression: a global public health concern. Diperoleh dari http://www.who.int/mental_health/managem ent/depression/who_paper_depression_wfm h_2012.pdf

Wulandari, A.F.S. (2011). Kejadian tingkat depresi pada lanjut usia: studi perbandingan di panti werdha dan komunitas (Tesis, Program Pascasarjana). Semarang: Fakultas Kedokteran Universitas Diponegoro.

Yuliati, A., Baroya, N., \& Ririanty, M. (2014). Perbedaan kualitas hidup lansia yang tinggal di komunitas dengan di pelayanan sosial lanjut usia (Tesis, Program Pascasarjana). Jember: Fakultas Kesehatan Masyarakat Universitas Jember. 